\title{
Ludwik Łysiak
}

\section{Raz jeszcze o zalożeniu sqdu wyższego prawa niemieckiego na zamku krakowskim}

\section{Noch einmal über die Gründung des Obergerichtshofes des Deutschen Rechtes im Krakauerschloss}

1. Zainteresowanie nauki założeniem sądu wyższego prawa niemieckiego na zamku krakowskim.

2. Czas i motywy utworzenia sądu wyższego - stanowisko literatury. 3. Sąd wyższy prawa niemieckiego na zamku krakowskim zaczątkiem reformy sądów wyższych w Małopolsce. 4. Rola sq̨du wyższego w kształtowaniu praktyki wymiaru sprawiedliwości.

1. Das Interesse der Wissenschaftler für die Gründung des Obergerichtshofes des Deutschen Rechtes im Krakauerschloss. 2. Zeit und Motive der Gründung des Obergerichtshofes - Stellungnahme der Litaralur. 3. Der Obergerichtshof des Deutschen Rechtes im Krakauerschloss als Anfang der Reform der oberen Gerichten in Małopolska [Kleinpolen]. 4. Der Anteil des Obergerichtshofes an der Praxisgestaltung der Gerichtsbarkeit.

1. Założenie sądu wyższego prawa niemieckiego na zamku krakowskim było niewątpliwie ważnym wydarzeniem $w$ dziejach państwa i prawa średniowiecznej Polski, a potwierdziły to również późniejsze jego dzieje, sięgające nieprzerwanie aż do ostatnich lat dawnej Rzeczypospolitej. Można dziśs stwierdzić, iż od połowy XIV w. do końca XVIII stulecia nie było w Polsce sądu, który dalby się porównać $z$ krakowskim sądem wyższym pod wielu względami, m. in. trwającym nieprzerwanie cztery i pól stulecia okresem funkcjonowania w niezmienionej formie organizacyjnej, terytorialnym zasięgiem działania obejmującym blisko połowę dawnej Korony, właściwością osobową i rzeczową we wszystkich sprawach należących do zakresu prawa niemieckiego, rozciągającą się na ogół ludności miejskiej i wiejskiej, a nierzadko także na szlachte $\mathrm{i}$ duchowieństwo szczególnie $\mathrm{w}$ sprawach niespornych; do tego dodać jeszcze należy wysoką częstotliwość i regularność posiedzeń sądowych, wiedzę prawniczą osób w tym sądzie zasiadających, oraz jakość wydawanych przezeń wyroków, które zapewniały mu wysoka pozycję i uznanie w środowisku, z którym był ciągle związany, wreszcie zachowaną dzięki dbałości jego 
wójtów i pisarzy niemal w komplecie, liczącą ok. 70 ksiąg, spuściznę aktową, umożliwiającą kompleksowe badania nad prawem niemieckim w dawnej Polsce, czego nie zapewniają zasoby aktowe wielu innych sądów tegoż prawa ${ }^{l}$. Nic więc dziwnego, że jeden $\mathrm{z}$ recenzentów powołanej tu pierwszej monografii o krakowskim sądzie wyższym prawa niemieckiego, już na wstępie zaznaczył, iż mamy tu do czynienia z klejnotem europejskiej historii prawa ${ }^{2}$. A mimo przytoczonych tu okoliczności, świadczących o niezwykłości naszego sądu, z całych kilkuwiekowych jego dziejów zainteresowanie nauki zarówno polskiej, jak też niemieckiej wzbudziło niemal wyłącznie samo tylko jego założenie i towarzyszące mu niektóre okoliczności, a zwłaszcza data wystawienia samego dokumentu fundacyjnego. Rzadko także w badaniach nad dziejami prawa niemieckiego w Polsce siegano do pozostałego po krakowskim sądzie wyższym zasobu aktowego, który z różnych względów, także językowych, może się okazać trudnym do wykorzystania. Lista niemieckich i polskich historyków oraz historyków prawa, którzy poświęcili w swoich pracach krótkie lub dłuższe wzmianki sądowi wyższemu prawa niemieckiego na zamku krakowskim, poczynając od połowy XIX w. po dzień dzisiejszy, jest wyjątkowo długa. Najliczniej występują na niej wydawcy aktu fundacyjnego sądu wyższego prawa niemieckiego na zamku krakowskim, jak również wydawcy pomników tego prawa i źródel praktyki sądowej na tym prawie opartej, autorzy zajmujący się recepcją tego prawa w Europie środkowowschodniej, kolonizacją na prawie niemieckim w Polsce, sądami wyższymi prawa niemieckiego, oraz położeniem prawnym ludności temu prawu podległej. Oto niektórzy $\mathrm{z}$ nich, wymienieni tu $\mathrm{w}$ porządku chronologicznym: C. Stobbe, J. W. Bandkie, A. Z. Helcel, R. Roepell, J. Fr. Behrend, G. Homeyer, M. Bobrzyński, F. Piekosiński, R. F. Kaindl, A. Brackmann, R. Kötschke, T. Görlitz, H. F. Schmid, A. Kłodziński, S. Kutrzeba, W. Weizsäcker, G. Schubart-Fikentscher, W. Kuhn, J. Weitzel, Z. Kaczmarczyk, M. Friedberg oraz zamykający tę listę L. Lysiak ${ }^{3}$.

2. Pomijam tu kwestię domniemanych błędów w datacji oraz $w$ formule świadków występujących $w$ dokumencie fundacyjnym krakowskiego sądu wyższego prawa niemieckiego. Wobec braku oryginału tego dokumentu trudno owe błędy wyjaśnić i wskazać jednoznaczne brzmienie odpowiednich

\footnotetext{
' L. Lysiak, Ius supremum Maydeburgense castri Cracoviensis, 1356-1794, Organisation, Tätigkeit und Stellung des Krakauer Oberhofs in der Rechtsprechung Altpolens, [w:] Ius Commune, Bd. 49, Frankfurt am Main 1990, s. 12-13.

2 J. W e ize l, Tijdschrift voor Rechtsgeschiedenis, t. LX, 1992, s. 206.

${ }^{3}$ Literaturę niemiecką do 1942 r. zestawia G. Schubart-Fikentscher (Die Verbreitung der deutschen Stadtrechte in Osteuropa, Weimar 1942, s. 527), polską do 1946 M. F r i ed b e r g (Kultura polska a niemiecka, Poznań 1946, s. 261 i n.).
} 
miejsc $w$ omawianym dokumencie. Niemniej z dużym prawdopodobieństwem opowiadam się za datą 1356 r., przytaczając jako uzasadnienie następujące okoliczności: po pierwsze - znane są dokumenty wystawione przez krakowski sąd wyższy prawa niemieckiego tuż po roku $1356 \mathrm{i}$ świadczące, iż sąd ten był już wówczas $w$ pełni zorganizowany na zasadach określonych $\mathrm{w}$ akcie fundacyjnym $\mathrm{z}$ 1356; po drugie - $\mathrm{w}$ ciągu calego czteroipólwiekowego okresu istnienia sądu krakowskiego w pozostałych po nim aktach, w tym również $w$ dokumentach pochodzących $z$ kancelarii królewskiej, wielokrotnie spotyka się odwołania do aktu fundacyjnego tegoż sądu, zawsze $\mathrm{z}$ datą $1356 \mathrm{r}$.; po trzecie - sąd wyższy prawa niemieckiego na zamku krakowskim w ciaggu owych długich 450 lat swego istnienia przeżywał nieraz ciężkie chwile i z całą determinacją musiał bronić swojej egzystencji, np. kiedy władze miasta Krakowa próbowały różnymi sposobami doprowadzić do jego likwidacji i przejęcia uprawnień wynikających $\mathrm{z}$ aktu fundacyjnego. Nigdy jednak nie padł pod adresem naszego sądu zarzut legitymowania się nieautentycznym dokumentem założycielskim, o wątpliwej dacie jego wystawienia i niepewnych świadkach tego wydarzenia. Sądzę zatem, że jeśli nawet gdzieś zdarzyła się pomyłka ze strony kancelarii królewskiej, nie miała ona $w$ tym przypadku większego znaczenia ${ }^{4}$.

Innego wyjaśnienia wymagają motywy założenia sądu wyższego prawa niemieckiego na zamku krakowskim, od których rozpoczyna się akt fundacyjny. W literaturze nie sa one jednoznacznie przedstawiane, a to $z$ kolei nasuwa różne intencje założyciela tego sądu i kierunki jego dalszego rozwoju w praktyce.

„Jako główny motyw uczynienia sądu krakowskiego - pisał przed laty Z. Kaczmarczyk - instancją wyższą wysunęła się kwestia uniezależnienia się sądów prawa niemieckiego w Polsce od zagranicy, to znaczy Niemiec, a specjalnie Magdeburga, zapewne też i od Środy czy Wrocławia leżących $w$ państwie wrogich Luksemburgów. $Z$ braku bowiem poważnych sądów wyższych w Polsce, wsie i miasta lokowane na prawie magdeburskim wysyłały zapytania prawne do wyżej wymienionych obcych sądów wzorowych względnie macierzystych, które za przesłane im objaśnienia, tzn. ortyle, kazały sobie słono placić. Nie trzeba chyba też bliżej wyjaśniać, jakie moralne znaczenie miała taka zależność od zagranicy (per que honori, decori, iurisdicioni, solio tribunali illibatis nostris predictis detrahatur et turpitudini reservetur). Z tym wszystkim Kazimierz Wielki - pisze dalej Kaczmarczyk - pragnął zerwać, i w dokumencie dla sądu krakowskiego, jak nigdzie może indziej, zaznacza się jego myśl o zupełnej suwerenności państwowej Polski, duma pełnej niezależności i odrębności, niecierpiąca

4 L. Ly siak, Ius supremum..., s. 23-25. 
żadnych obcych ingerencji nawet w dziedzinie prawnych zasad"s. Podobnie wypowiada się na temat założenia krakowskiego sądu wyższego J. Bardach: „Aby zapobiec zwracaniu się nadal po ortyle i z apelacjami do Magdeburga, co uważano za niezgodne $\mathrm{z}$ suwerennością państwową Królestwa, Kazimierz Wielki powołal dla Małopolski sąd wyższy prawa niemieckiego zamku krakowskiego jako prowincjonalny sąd leński dla wójtów i sołtysów z dóbr królewskich, oraz upoważnił go do wydawania pouczeń innym sądom prawa niemieckiego $\mathrm{w}$ Małopolsce. Pomimo istnienia sądu wyższego na zamku krakowskim powstały nowe sądy leńskie (w Małopolsce znamy ich ogółem 11), będące też sądami wyższymi glównie w dobrach prywatnych"". Przytoczone tu opinie Z. Kaczmarczyka i J. Bardacha wymagają pewnego komentarza.

Zamknięcie drogi polskim sądom prawa niemieckiego do Magdeburga uzupełniają niektórzy autorzy dodatkową jeszcze argumentacją, zaczerpniẹtą także $\mathrm{z}$ treści pierwszego zdania aktu fundacyjnego, wskazując na dampnum et regnicolarum nostrorum gravamen, co należy rozumieć jako koszty ortyli i podróży, ponoszone przez strony procesowe ${ }^{7}$. Nie jest to jednak argument przekonujący, ponieważ koszty takie $w$ każdym procesie strony musiały ponosić, niezależnie od tego, czy toczyły się one przed sądem krajowym, czy też zagranicznym. Koszty podróży natomiast zależnie od odległości pomiędzy siedzibą sądu pierwszej instancji a sądem wyższym również spadały na skarżące się strony bezpośrednio lub - jak to bywało w przypadku krakowskiego sądu wyższego prawa niemieckiego - jako rekompensata dla specjalnych cursores. Dodajmy tu od razu, iż odległości sądów Małopolskich, zwłaszcza z terenu Małopolski wschodniej, od Krakowa były nieraz równe odległościom między Krakowem a Magdeburgiem. Ich pokonywanie więc nie odbywało się ze szkodą i uciążliwością Królestwa i jego mieszkańców". Lament J. Ostroroga trzeba więc uznać za spóźniony i nieco przesadzony9.

3. Zakaz odwoływania się polskich sądów prawa niemieckiego do Magdeburga wydany został w szczególnej sytuacji. Oto bowiem osadnictwo na prawie niemieckim $w$ połowie XIV $w$. osiągneło $w$ Polsce taki poziom rozwoju, iż odpowiednie zaplecze prawne dla uczestniczącej $w$ tym procesie ludności miejskiej i wiejskiej stało się nadzwyczaj pilne. Na przeszkodzie

${ }^{5}$ Z. Kaczmarczyk, Monarchia Kazimierza Wielkiego, t. I, Organizacja państwa, Poznań 1939 , s. 2 i n.

${ }^{6} \mathrm{~J}$. Bardach, E. Leśnodorski, M. Pietrzak, Historia ustroju i prawa polskiego, Warszawa 1993, s. 122.

${ }^{7}$ L. Ey sia $\mathrm{k}$, Ius supremum..., s. 171.

${ }^{8}$ Ibidem, s. 77.

${ }^{9}$ J. Ostroróg, Monumentum pro Reipublicae ordinatione, SPPP, t. V/1, Kraków 1878, s. 126. 
w szybkiej realizacji tego zadania stanęly od razu dwie okoliczności, a mianowicie: brak znajomości prawa niemieckiego wśród osadników polskiego pochodzenia oraz brak odpowiedniej sieci sądów tegoż prawa, ze szczególnym uwzględnieniem sądów wyższych zdolnych do rozpatrywania odwolań $\mathrm{i}$ udzielania pouczeń. Pierwszy $\mathrm{z}$ tych braków objawiał się $\mathrm{w}$ praktyce częstym podówczas korzystaniem $\mathrm{z}$ łatwo dostępnych sądów prawa polskiego, mimo przeniesienia danej miejscowości już wcześniej na prawo niemieckie. Znając tę praktykę i jej szkodliwe następstwa dla całego wymiaru sprawiedliwości, Kazimierz Wielki w swoich statutach z połowy XIV w. postanawia: Plures sunt nostri milites ius Teutonicum habentes in multis ipsorum villis ex nostra aut nostrorum predecessorum gratia eis facta, et tamen iure Teutonico omisso secundum ius Polonicum se regunt in quibusdam. Statuimus, quod si in aliqua villa abusi sunt iure Teutonico, amplius contra ius agentes per ius Teutonicum non poterunt se defensare ${ }^{10}$. Trudno ustalić, jak dalece skutecznym okazał się przytoczony wyżej przepis statutowy; w praktyce bowiem jeszcze długo po jego wydaniu spotykamy ludność wiejską poza zasięgiem jurysdykcyjnym własnych sądów, a remisje ad ius hereditarium stały sie wcale częstym zjawiskiem w praktyce sądowej.

Drugi $\mathrm{z}$ wymienionych wyżej braków, utrudniający zaprowadzenie ładu i porządku w wymiarze sprawiedliwości opartym na zasadach prawa niemieckiego, był $w$ polowie XIV w. równie trudny do realizacji $w$ praktyce, co pierwszy. Krajowa sieć sądów wyższych prawa niemieckiego w Polsce byla wówczas jeszcze zbyt wątła liczebnie oraz nie zawsze należycie przygotowana i wyposażona w źródła prawa i praktyki sądowej. W tej sytuacji trudno dziwić się, że sądy polskie prawa niemieckiego szukały pomocy prawnej w sądach obcych, szczególnie w Magdeburgu, kierując tam odwołania i zabiegając o pouczenia. Stan taki utrzymywał się w polskim systemie sądów wyższych prawa niemieckiego dość długo, niekiedy nawet w głąb XVI stulecia, kiedy to sądy wyższe prawie wszędzie zaprzestały swej działalności. Los taki spotkal wszystkie kategorie tych sq̨dów, których w Małopolsce było ponad 20; jedne $z$ nich zanikły wskutek braku spraw, inne $-\mathrm{z}$ powodu przeksztalcenia się solectw i wójtostw $w$ dobra ziemskie, podległe prawu polskiemu, jeszcze inne - wskutek zamykania się sądownictwa wiejskiego w kręgu jurysdykcyjnym wielkiej własności ziemskiej ${ }^{11}$.

Aby wyjaśnić do końca problem zależności sądów polskich prawa niemieckiego od ośrodków zagranicznych, a szczególnie od Magdeburga, trzeba odpowiedzieć na jedno jeszcze pytanie: czy mieszkańcy miast i wsi polskich zwracali się do Magdeburga po ortyle, a później także w trybie

${ }_{10}$ Polskie statuty ziemskie $w$ redakcji najstarszych druków (Syntagmata), opr. L. Lysiak i S. Roman, Wrocław-Kraków 1958, PPP, dz. I, t. II, s. 89-90.

${ }^{11} \mathrm{~L} . \mathrm{Łysiak}$, Höhere Gerichte des deutschen Rechts in Polen, [w:] Rechtsbehelfe, Beweis und Stellung des Richters im Spätmittelalter, Hrsg. W. Sellert, Köln-Wien 1985, s. 33. 
apelacji tylko sporadycznie, czy też była to praktyka stała i częsta. Pierwsze zdanie aktu fundacyjnego krakowskiego sądu wyższego z $1356 \mathrm{r}$. zredagowane zostało w tonie stanowczym i ostrym, nie dopuszczającym żadnego sprzeciwu ani wyjątku.

Podobnie na ten temat wypowiedzial się tylko Jan Ostroróg, ale uczynił to ok. $1470 \mathrm{r}$., kiedy już takiej potrzeby w ogóle nie było. W porównaniu z przedstawionym wyżej stanem sądownictwa wyższego prawa niemieckiego $\mathrm{w}$ Polsce $\mathrm{z}$ połowy XIV $\mathrm{w}$. może ten ostry ton wydawać się nieco dziwny, a nawet niezrozumiały. Wszak pomoc Magdeburga, czy też innego z miast macierzystych, była Polsce w tym czasie naprawdę potrzebna, jak o tym świadczą rozrzucone po różnych XIX-wiecznych wydawnictwach pojedyncze ortyle magdeburskie dla Krakowa, bądź nawet całe zbiory kilkuset takich pouczeń $^{12}$. A ileż krążyło po średniowiecznej Polsce różnych zbiorów prawa niemieckiego i magdeburskiego, bez których polskie sądy $w$ ogóle nie mogłyby funkcjonować. Jeden $\mathrm{z}$ takich zbiorów otrzymał od Kazimierza Wielkiego także krakowski sąd wyższy, przy okazji jego założenia. Czy ten fakt można także uznać za ograniczenie suwerenności, podobnie jak wydane wyroki i udzielone pouczenia?

Wracając do postawionego wyżej pytania dotyczącego częstotliwości kontaktów prawnych polsko-niemieckich $w$ połowie XIV w. wydaje się, iż przy obecnym stanie źródel trudno będzie nawet $w$ przybliżeniu je ustalić. Niewątpliwie mógłby tu pomóc Das Institut zur Erforschung des Magdeburger Stadtrechts, gdyby jego materiały zachowały się $w$ komplecie ${ }^{13}$. Pewne sugestie w tym kierunku nasuwają tylko XIX-wieczne publikacje magdeburskich ortyli, pozwalające przypuszczać, iż $w$ chwili organizowania sądu wyższego prawa niemieckiego na zamku krakowskim kontakty te były jeszcze stosunkowo częste. $Z$ czasem jednak, w miarę umacniania się systemu sądownictwa wyższego, a przede wszystkim sądów małopolskich z krakowskim sądem wyższym na czele, pomoc prawna Magdeburga stawała się coraz mniej potrzebna. Dowodzą tego $\mathrm{m}$. in. późniejsze potwierdzenia królewskie aktu fundacyjnego z 1356 r., w których ten fragment jego tekstu już opuszczano. Wydaje się nawet, iż w pewnym stopniu byl on już zbędny w czasie, kiedy Jan Ostroróg pisał swój niezwykły sprzeciw De iure ex Maydemburg petendo (ok. 1470 r.). W konkluzji można raczej przyjąć, iż korzystanie $\mathrm{z}$ pomocy prawnej sądu magdeburskiego $\mathrm{w}$ okolicznościach, jakie wystąpily $w$ Polsce $w$ połowie XIV w., nie miało zbyt wyraźnych znamion ograniczenia suwerenności Królestwa Polskiego. W przeciwnym

${ }_{12}$ Über eine Sammlung deutscher Schöffensprüche in einer Krakauer Handschrift, von F. Bischoff, [w:] Archiv für österreichische Geschichte, Bd. 38, Wien 1867.

${ }_{13}$ T. Görlit z, Das Institut zur Erforschung des Magdeburger Stadtrechts. Stand und Aufgaben der Forschung über das Magdeburger Stadtrecht, insbesondere seine Verbreitung zwischen Ostsee und Schwarzem Meer, 1942, s. 98. 
bowiem razie trudno byłoby pogodzić tę suwerenność z szerokim otwarciem granicy zachodniej państwa na nieograniczony napływ osadników niemieckich do Polski, z pełną recepcją prawa niemieckiego, $\mathrm{z}$ organizacją sądownictwa krajowego na tym prawie opartego, jak również $\mathrm{z}$ nieograniczonym stosowaniem języka niemieckiego $w$ polskiej praktyce sądowej. Co najwyżej, zakaz odwoływania się do Magdeburga można traktować jako środek prewencyjny na wypadek, gdyby wystąpiły okoliczności rzeczywiście zagrażające polskiej suwerenności. Opublikowane przez nas dekrety sądu wyższego prawa niemieckiego na zamku krakowskim $\mathrm{z}$ lat 1456-1511 świadczą, iż $w$ poruszanych tu kwestiach odwołań i udzielania pouczeń prawnych sądom niższym $z$ terenu Małopolski, krakowski sąd wyższy prawa niemieckiego nie miał żadnych kłopotów ${ }^{14}$.

Et quod deterius est (i co gorsze) - czytamy w dalszej części motywów uzasadniających powołanie do życia sądu wyższego prawa niemieckiego na zamku krakowskim: wójtowie, sołtysi, ławnicy przysięgli jurysdykcji niemieckich, nie mogąc podjąć decyzji w trudniejszych sprawach $\mathrm{z}$ braku odpowiednich kwalifikacji, zwracają się do rajców, wójtów i lawników niektórych miast Królestwa, którym nie została przez nas udzielona moc wyrokowania $\mathrm{w}$ sprawach $\mathrm{z}$ zakresu prawa magdeburskiego jako sądom wyższym, nec potestas ad vendendum ius supremum nostro solio et tribunali de iure dumtaxat annexum [...] extra fines eorum iurisdicionis [...] insontesque contendentes deludebant, sumptibus, laboribus, impensis et expensis fatigando minus iuste, contra que in nostro regno clamor ascendit [...] quod sine scandalo tollerari per nostram serenitatem oculis conniventibus pertransiri non potuerunt $^{15}$. A zatem, co było gorszym zlem dla polskiego wymiaru sprawiedliwości opartego na prawie niemieckim: fakt szukania tej sprawiedliwości poza granicami państwa $w$ niemieckich miastach macierzystych z Magdeburgiem na czele, czy też korzystanie $\mathrm{z}$ usług krajowych sądów wyższych, uzurpujących sobie prawo do wydawania wyroków i udzielania sądom niższym pouczeń, bez odpowiedniego zezwolenia na taką działalność ze strony panującego. Akt fundacyjny krakowskiego sądu wyższego prawa niemieckiego z $1356 \mathrm{r}$. rozstrzyga sam, co jest tu gorsze, i opowiada się jednoznacznie za legalnie działającymi z upoważnienia królewskiego sądami wyższymi. W przeciwnym razie grozi Królestwu Wielki „krzyk” i „skandal”. I tu widzę główny motyw powolania do życia sądu wyższego prawa niemieckiego na zamku krakowskim, który w planach Kazimierza Wielkiego mial dokonać reformy w całym systemie sądów wyższych na terenie Mało-

${ }^{14}$ Decreta iuris supremi Magdeburgensis castri Cracoviensis 1456-1481, Hrsg. L. Lysiak und K. Nehlsen-v. Stryk, [w:] lus Commune, Bd. 68, Frankfurt am Main 1995. Decreta iuris supremi Magdeburgensis castri Cracoviensis, Bd 2: 1481-1511, Hrsg. L. Łysiak, [w:] Ius Commune, Bd. 104, Frankfurt am Main 1997.

15 L. Ły s ia k, Ius supremum..., s. 172-173. 
polski, a z czasem - być może - także na terenie całego kraju. Zakaz odwoływania się do Magdeburga miał być - jak sądzę - tylko punktem wyjścia i uzasadnieniem reformy, bez której sądy prawa niemieckiego wszystkich szczebli nie mogły sprawnie funkcjonować.

4. O tym, że w małopolskich sądach wyższych nie działo się najlepiej, może świadczyć m. in. skarga przeciw sądowi miejskiemu w Żarnowcu z 1510 r., występującemu w roli nielegalnego sądu wyższego, i wyrok wyższego - krakowskiego, kasujący sentencję tego sądu z takim oto uzasadnieniem: Quod vero tetigistis de iure superiori opidi Żarnowiec, hoc scire debetis, quod nec in Żarnowiec nec alias ius supremum est fundatum solum in castro Cracoviensi, ad quod ex omnibus partibus Regni pro iure recipiendo confugium merito habetur. Quod vero iurati vestri vobis retulerunt, ut quicunque ortilegium opidi Zarnowiec pro iure suscipere recusaverit, ille $X$ marcas domino hereditario solvere deberet, quod non est forma iuris, neque ius scriptum istud dictat, quod alicui per penas aliquas pecuniarias iusticia iuris et eius processus deberet claudi, ideo si aliquod impedimentum propterea haberetis, potestis in hoc ad nostrum ius confugere a nobisque informacionem postulare, nosque vobis consilium salubre dare non recusabimus ${ }^{16}$. Oto przykładowy powód owego „krzyku”, docierającego także do uszu królewskich, i przyczyna główna powołania do życia sądu wyższego prawa niemieckiego na zamku krakowskim. A że był taki sąd szczególnie potrzebny, gotowy w każdej chwili udzielić pomocy prawnej innym sądom prawa niemieckiego niższego szczebla, świadczą najlepiej tysiące spraw, które krakowski sąd wyższy załatwiał w drugiej, trzeciej, a niekiedy nawet czwartej instancji ${ }^{17}$.

Przytoczone wyżej zdanie drugie aktu fundacyjnego krakowskiego sądu wyższego prawa niemieckiego wyjaśnia nam nie tylko motywy jego założenia, ale również przesądza o jego nadrzędności wobec wszystkich innych sądów wyższych z terenu Małopolski. Na przełomie XIV i XV w. działało tu - jak już wyżej wspomniałem - ponad 20 takich sądów i wszystkie one rychło stały się klientami sądu wyższego na zamku krakowskim, który dla spraw przychodzących $\mathrm{z}$ innych sądów wyższych często był już trzecią instancją. Publikowane przez nas dekrety sądu krakowskiego odnotowują często ten fakt już w samym naglówku zapiski.

Nadzór nad sądami wyższymi niższego szczebla sprawował sąd wyższy na zamku krakowskim w różnych formach. Najczęstszą z nich była oczywiście kasacja wyroków wydanych przez niższą instancję, co w praktyce zdarzało się dość często. Zależało to od różnych okoliczności, $w$ tym $\mathrm{m}$. in. od

${ }^{16}$ Decreta..., Bd. 2, Nr 1100.

${ }^{17}$ L. Ly siak, Ius supremum..., s. 114, anm. 160. 
kwalifikacji fachowych sądów niższych, jak również od kwalifikacji pełnomocników procesowych, których rola $w$ procesach toczących się przed sądami prawa niemieckiego była zazwyczaj znacząca. Sąd wyższy prawa niemieckiego na zamku krakowskim, otrzymawszy sprawę $\mathrm{z}$ sądu niższej instancji, badał dokładnie zawartość każdego rotułu, a stwierdziwszy zachodzące w nim braki, odsyłał go do uzupełnienia lub poprawki, czyniąc przy tej okazji mniej lub bardziej krytyczne uwagi. Oto np. pisze krakowski sąd wyższy w 1458 r. do Kleparza: Amici carissimi, miramur de vobis, quod vos tam simplicem materiam, quam dominus noster rex suas per litteras vobis clarius pronunciare et ad iudicium vestre civitatis vobis demandavit, intelligere non poteritis ${ }^{18}$. W tym samym roku zwraca się krakowski sąd wyższy do Piotrkowa: Scribitis nobis litteram pro sentencia vobis danda valde obscuram et coopertam, ex qua discernere non possumus [...] quapropter de iure scribere nobis debetis lucide et aperte ${ }^{19}$. Zaś w 1465 r. pisze krakowski sąd wyższy do Skarbimierza: scriptis vestris miramur, quomodo in una et eadem causa semper aliter et aliter scribiti ${ }^{20}$. Te $\mathrm{i}$ inne przyklady świadcza, iż krakowski sąd wyższy nie odmawial pomocy skarżącym się stronom, ale często domagał się od nich większej staranności $w$ przygotowaniu sprawy, co można uznać za dobrą szkołę praktycznego kształcenia $\mathrm{w}$ zawodzie prawniczym.

\footnotetext{
${ }_{18}$ Decreta..., Bd. 1, Nr 166.

19 Ibidem, Nr 193.

${ }^{20}$ Ibidem, Nr 688.
} 